\title{
PERBANDINGAN PENAWARAN INVESTASI DEPOSITO BANK SYARIAH
}

\author{
Hery Harjono Muljo ${ }^{1}$; Holly $D^{2}$ \\ ${ }^{1,2}$ Jurusan Akuntansi, Fakultas Ekonomi dan Bisnis, Universitas Bina Nusantara \\ Jln. K.H. Syahdan No. 9, Palmerah, Jakarta Barat 11480 \\ heryhm@binus.edu; bunda_mustafa@yahoo.com
}

\begin{abstract}
From the beginning, the sharia banks operation is always supporting mosleem expectations. Economic recovery, fairness, security, and comfortness aspects are became ultimate goals of sharia bank in Indonesia. This research is comparing the investment deposits from 3 sharia banks, and 4 business units of sharia, by using comparative descriptive analysis. The comparative variables were devided into 3 categories; there are Nisbah (profit sharing), investment conditions, and bank fascilities. The results indicates that BNI has the highest nisbah between all sharia banks at the first category. Bank Muamalat Indonesia, BNI Sharia, Bank Sharia Mega Indonesia has the lowest openning balance of time-deposits at second category. The product fascility as the third category, indicates that Bank Sharia Mandiri, BNI Sharia, Bank Sharia Mega Indonesia, and Bank Muamalat can using multi currency. BTN Sharia, Bank Sharia Mega Indonesia, Bank Muamalat Indonesia, and Bank Danamon Sharia were also offer joint account in their sharia investment.
\end{abstract}

Keywords: Syariah Bank, quality, time-deposits

\begin{abstract}
ABSTRAK
Bank syariah dari awal bermulanya beroperasi hingga masa sekarang, menyimpan berbagai harapan bagi ummat Muslim. Perbaikan perekonomian, keadilan, keamanan, serta kenyamanan adalah tujuan utama dari keberadaan Bank Syariah di tanah air. Penelitian perbandingan penawaran investasi deposito dilaksanakan di 3 bank syariah dan 4 unit usaha syariah, dengan pendekatan deskriptif komparatif. Varibel pembanding terdiri dari 3 kelompok, yaitu: Kelompok 1 (nisbah keuntungan bagi hasil), kelompok 2 (persyaratan penempatan deposito), dan kelompok 3 (fasilitas). Pada kelompok 1 BNI Syariah memiliki nisbah tertinggi dibandingkan dengan bank syariah lainnya, kelompok 2 untuk minimum terendah jumlah Rupiah penempatan deposito adalah Bank Muamalat Indonesia, BNI Syariah dan Bank Syariah Mega Indonesia, sedangkan di kelompok 3 untuk fasilitas Bank Syariah Mandiri, BNI Syariah, Bank Syariah Mega Indonesia, dan Bank Muamalat Indonesia memiliki pilihan untuk mata uang asing, joint account dapat dilaksankan di BTN Syariah, Bank Syariah Mega Indonesia, Bank Muamalat Indonesia, dan Bank Danamon Syariah
\end{abstract}

Keywords: Bank Syariah, kualitas, deposito 


\section{PENDAHULUAN}

Bank Syariah pada saat ini tengah mengalami kemajuan yang sangat pesat, bank konvensionalpun seakan berlomba untuk memenuhi pangsa pasar yang menuntut keberadaan bank syariah atau minimal unit usaha syariah. Keberadaan bank syariah dibutuhkan sebagai transaksi keuangan, baik dimanfaatkan sebagai pinjaman atau sebagai penyimpanan uang. Harapan utama di tengah masyarakat akan keberadaan bank syariah adalah memberikan ketenangan dan keamanan. Bank umum pertama yang menggunakan system syariah di Indonesia yaitu Bank Muamalat Indonesia (BMI) yang mulai beroperasi pada 1992. Menyusul pada tahun 1998 didirikan Bank Syariah Mandiri (BSM) yang merupakan anak perusahaan Bank Mandiri, bank BUMN terbesar di Indonesia. Selanjutnya disusul kembali oleh Bank Syariah Mega Indonesia di tahun 2001. Memasuki tahun 2009 ini ada dua bank baru ikut meramaikan pasar bank syariah yaitu Bank Bukopin Syariah dan BRI Syariah. Unit Usaha Syariah diantaranya adalah BNI, Bank Danamon, BII, HSBC, BTN, Bank Permata, dan BCA.

Sementara itu, berdasarkan survei BI selama dua tahun terakhir ini minat masyarakat terhadap bank syariah di daerah cukup besar. Dalam tiap provinsi yang mayoritas muslim, hampir separuhnya menghendaki pelayanan perbankan syariah. Sekitar $11 \%$ sudah mengerti produk dan layanan yang ditawarkan. Besarnya kebutuhan layanan syariah di daerah, mendorong sejumlah bank daerah membuka Unit Usaha Syariah (UUS). Saat ini terdapat 16 BPD sudah membuka UUS, yaitu Bank NTB, Bank Sumut, Bank Aceh, Bank Sumsel dan lain-lain. Sebelumnya sudah ada unit syariah BPD DKI Jakarta, BPD Jabar-Banten, BPD Riau, BPD Kalbar, BPD Kalsel dan BPD Sulsel. Dalam tinjauan kebijakan moneter hingga Agustus 2009 Dana Pihak Ketiga (DPK) meningkat 39,56\% bila dibandingkan dengan posisi yang sama 2008, yaitu dari Rp32,36 triliun menjadi Rp45,16 triliun. Secara umum, deposito mudharabah memberikan kontribusi terbesar (56,04\%), diikuti oleh tabungan mudharabah (31,78\%) dan giro wadi'ah (12,18\%).

Dibandingkan dengan pertumbuhan DPK bank konvensional yang hanya berkisar pada angka $3 \%$, maka pertumbuhan ini cukup menggembirakan. Persaingan yang sangat ketat di antara bank yang ada dalam menarik dana masyarakat mewarnai kompetisi dunia perbankan sepanjang tahun ini. Bila pertumbuhan DPK bank syariah unggul, itu karena secara rasional tingkat bagi hasil yang ditawarkan bank syariah sangat kompetitif dibandingkan dengan tingkat suku bunga bank konvensional. Ditambah lagi dengan pemahaman masyarakat terhadap perbankan syariah yang semakin luas. Selain itu, bertambahnya jaringan kantor bank syariah juga menjadi faktor pendukung. Penambahan jaringan yang ada menyebabkan masyarakat semakin mudah bertransaksi secara syariah. Dana masyarakat ini menyumbang $87,4 \%$ dari total sumber dana bank syariah. Bank syariah memberikan pembagian hasil yang sangat menarik bagi nasabah sehingga memiliki persentase pertumbuhan perhimpunan DPK perbankan syariah lebih tinggi dibandingkan bank konvensional, oleh karena hal tersebut kami melakukan penelitian kualitas jasa bank syariah keterkaitan dengan penyimpanan DPK khususnya deposito. Tujuan dari penelitian ini adalah membandingkan penawaran investasi depostio oleh masingmasing bank syariah. Variabel yang dibandingkan adalah nisbah keuntungan bagi hasil, persyaratan penempatan deposito, dan fasilitas seperti pilihan mata uang asing, dan joint account untuk pembukaan deposito.

\section{METODE PENELITIAN}

Untuk membandingkan penawaran investasi deposito bank syariah, pendekatan penelitian yang diambil adalah deskriptif komparatif. Penelitian dilakukan dengan membandingkan 3 bank syariah (Bank Muamalat, Bank Syariah Mandiri, dan Bank Syariah Mega Indonesia), dan 4 UUS 
(Bank Danamon Syariah, BNI Syariah, BTN Syariah, dan Bank DKI Syariah). Variabel pembandingnya adalah nisbah keuntungan, prasyarat menyimpan deposito dari bank Syariah, dan program fasilitas yang ditawarkan bank syariah seperti penyediaan penyimpanan deposito dalam mata uang asing, waktu penerimaan bagi hasil, pembukaan deposito, biaya materai deposito, dan lain-lain yang berkenaan dengan penyimpanan deposito.

\section{HASIL DAN PEMBAHASAN}

Berikut penjabaran data hasil survei yang telah dilakukan pada 3 bank syariah dan 4 UUS.

\section{Nisbah}

Nisbah (rasio) adalah porsi/besaran bagian yang menjadi hak masing-masing pihak pada proses distribusi bagi hasil antara Nasabah dengan Bank. Angka di depan (misalnya angka 60 pada 60:40) berarti 60\% merupakan porsi untuk Nasabah dan 40\% nya lagi merupakan porsi bank.

Berikut informasi nisbah Februari 2009 di Bank Muamalat Indonesia (BMI).

\begin{tabular}{cccc}
\hline $\begin{array}{c}\text { Jenis Simpanan } \\
\text { (Rp) }\end{array}$ & $\begin{array}{c}\text { Nisbah } \\
\text { (Nasabah) }\end{array}$ & $\begin{array}{c}\text { Hi-1000 } \\
\text { (Nasabah) }\end{array}$ & $\begin{array}{c}\text { Ekuivalen } \\
\text { Rate }\end{array}$ \\
\hline Deposito 1 bulan & 50,00 & 5.61 & $7.31 \%$ \\
Deposito 3 bulan & 51,00 & 5.72 & $7.46 \%$ \\
Deposito 6 bulan & 53,00 & 5.95 & $7.76 \%$ \\
Deposito 12 bulan & 54,00 & 6.05 & $7.90 \%$ \\
\hline
\end{tabular}

Berikut informasi nisbah BMI untuk jenis simpanan US\$

\begin{tabular}{lccc}
\hline $\begin{array}{c}\text { Jenis Simpanan } \\
\text { Valas }\end{array}$ & $\begin{array}{c}\text { Nisbah } \\
\text { (Nasabah) }\end{array}$ & $\begin{array}{c}\text { Hi-1000 } \\
\text { (Nasabah) }\end{array}$ & $\begin{array}{c}\text { Ekuivalen } \\
\text { Rate }\end{array}$ \\
\hline Deposito 1 bulan & 51,00 & 0.90 & $1.17 \%$ \\
Deposito 3 bulan & 51,25 & 0.90 & $1.17 \%$ \\
Deposito 6 bulan & 51,50 & 0.91 & $1.19 \%$ \\
Deposito 12 bulan & 51,75 & 0.91 & $1.19 \%$ \\
Tabungan & 22,00 & 2.47 & $3.22 \%$. \\
\hline
\end{tabular}

Berikut informasi nisbah November 2009 di Bank Syariah Mega Indonesia (BSMI)

\begin{tabular}{lcc}
\hline \multicolumn{1}{c}{ Jenis Simpanan } & Nisbah (Nasabah) & Bank \\
\hline Deposito 1 bulan & 26 & 74 \\
Deposito 3 bulan & 25,5 & 74,5 \\
Deposito 6 bulan & 25 & 75 \\
Deposito 12 bulan & 25 & 75 \\
\hline
\end{tabular}

Keterangan di atas adalah untuk jenis penyimpanan deposito minimum Rp.1.000.000,00 hingga Rp. 400.000.000,00. Persentase tersebut akan meningkat untuk pihak nasabah apabila jumlah deposito nasabah meningkat. 
Berikut informasi nisbah November 2009 BTN Syariah

\begin{tabular}{lcc}
\hline \multicolumn{1}{c}{ Jenis Simpanan } & Nisbah (Nasabah) & Bank \\
\hline Deposito 1 bulan & 50 & 50 \\
Deposito 3 bulan & 50 & 50 \\
Deposito 6 bulan & 51 & 49 \\
Deposito 12 bulan & 51 & 49 \\
\hline
\end{tabular}

BTN Syariah memiliki pembagian nisbah yang cukup bersaing. Pada saat ini bank BTN belum menerima deposito dollar.

Berikut informasi nisbah November 2009 Bank DKI Syariah

\begin{tabular}{lccc}
\hline $\begin{array}{c}\text { Jenis Simpanan } \\
\text { (Rp) }\end{array}$ & $\begin{array}{c}\text { Nisbah } \\
\text { (Nasabah) }\end{array}$ & $\begin{array}{c}\text { Hi-1000 } \\
\text { (Nasabah) }\end{array}$ & $\begin{array}{c}\text { Ekuivalen } \\
\text { Rate }\end{array}$ \\
\hline Deposito 1 bulan & 55 & 7.49 & 45 \\
Deposito 3 bulan & 55 & 7.49 & 45 \\
Deposito 6 bulan & 55 & 7.49 & 45 \\
Deposito 12 bulan & 55 & 7.49 & 45 \\
\hline
\end{tabular}

Berikut Informasi nisbah Bank DKI Syariah untuk jenis simpanan US\$

\begin{tabular}{lcc}
\hline $\begin{array}{c}\text { Jenis Simpanan } \\
\text { Valas }\end{array}$ & Nisbah (Nasabah) & Bank \\
\hline Deposito 1 bulan & 20,85 & 79,15 \\
Deposito 3 bulan & 20,85 & 79,15 \\
Deposito 6 bulan & 20,85 & 79,15 \\
Deposito 12 bulan & 20,85 & 79,15 \\
\hline
\end{tabular}

Bank DKI Syariah menawarkan nisbah deposito diatas lebih tinggi dibandingkan dengan BMI, BTN Syariah, dan BSMI.

Berikut informasi nisbah November 2009 di Bank Syariah Mandiri (BSM)

\begin{tabular}{lccc}
\hline \multicolumn{1}{c}{ Jenis Simpanan } & Nisbah (Nasabah) & Equivalent Rate & Bank \\
\hline Deposito 1 bulan & 51 & 6.45 & 49 \\
Deposito 3 bulan & 52 & 6.58 & 48 \\
Deposito 6 bulan & 53 & 6.7 & 47 \\
Deposito 12 bulan & 54 & 6.83 & 46 \\
\hline
\end{tabular}

BSM, memiliki nisbah yang cukup bersaing diantara BMI, BTN Syariah, ataupun BSMI untuk jenis deposito Rupiah

Berikut informasi nisbah November 2009 di Bank BNI Syariah adalah sebagai berikut:

\begin{tabular}{lcc}
\hline $\begin{array}{c}\text { Jenis Simpanan } \\
\text { Valas }\end{array}$ & Nisbah (Nasabah) & Bank \\
\hline Deposito 1 bulan & 64 & 36 \\
Deposito 3 bulan & 66 & 34 \\
Deposito 6 bulan & 68 & 32 \\
Deposito 12 bulan & 70 & 30 \\
\hline
\end{tabular}


Berikut informasi nisbah November 2009 di Bank Danamon Syariah

\begin{tabular}{lcc}
\hline $\begin{array}{c}\text { Jenis Simpanan } \\
\text { Valas }\end{array}$ & Nisbah (Nasabah) & Bank \\
\hline Deposito 1 bulan & 57 & 43 \\
Deposito 3 bulan & 60 & 40 \\
Deposito 6 bulan & 62 & 38 \\
Deposito 12 bulan & 65 & 35 \\
\hline
\end{tabular}

Persentase deposito Bank Danamon Syariahpun termasuk tinggi karena memiliki penawaran nisbah bersaingnya mencapai rata-rata $60 \%$ tapi, Bank Danamon juga memiliki persyaratan penyimpanan deposito tertinggi yaitu minimal Rp 8.000.000,-. Dapat disimpulkan bahwa dari evaluasi perbandingan ke 3 bank dan 4 UUS tersebut Bank BNI Syariah memiliki pembagian nisbah deposito Rupiah yang tertinggi dibandingkan dengan bank-bank lainnya, karena memiliki penawaran hingga mencapai $70 \%$.

\section{Minimum Penempatan Deposito}

Setiap bank memiliki kebijakan penempatan dana minimum untuk deposito sesuai dengan yang telah ditetapkan oleh Bank Indonesia. Beberapa bank syariah memberikan kesempatan kepada nasabah menengah untuk memiliki simpanan deposito minimum sebesar Rp.1.000.000,- dibandingkan dengan bank konvensional yang pada umumnya mensyaratkan minimum penempatan Rp 8.000.000,-

\begin{tabular}{llc}
\hline \multicolumn{1}{c}{ Nama Bank } & Deposito (Rp) & Deposito (\$) \\
\hline Bank Mandiri Syariah & Rp. 2,000,000 & $\$ 500$ \\
Bank Danamon Syariah & Rp. 8,000,000 & \\
Bank Muamalat & & \\
1. Deposito Fulinves & Rp. 2,000,000 & $\$ 500$ \\
2. Deposito Mudharbah & Rp. 1,000,000 & \\
Bank DKI Syariah & Rp. 2,000,000 & $\$ 500$ \\
BTN Syariah & Rp. 2,000,000 & \\
BNI Syariah & Rp. 1,000,000 & $\$ 500$ \\
Bank Syariah Mega Indonesia & Rp. 1,000,000 & $\$ 500$ \\
\hline
\end{tabular}

Biaya administrasi deposito dikenakan sebesar 20\%, apabila nilai deposito sudah melebih melebihi Rp.7,500,000.-. Disimpulkan bahwa BMI, BSMI, dan BNI Syariah memiliki persyaratan penyimpanan deposito terendah yaitu Rp.1.000.000. Sedangkan persyaratan penyimpanan deposito yang tertinggi adalah Bank Danamon Syariah yaitu Rp. 8.000.000.

\section{Fasilitas Bank Syariah}

\section{Pilihan Jangka Waktu dan Mata Uang}

Seluruh bank syariah, pada umumnya memiliki jangka waktu penyimpanan deposito antara 1 bulan hingga 12 bulan. Berikut data ketersediaan bank syariah dalam hal menyimpan deposito dalam mata uang asing: 


\begin{tabular}{lcc}
\hline \multicolumn{1}{c}{ Bank } & Rupiah & Dollar \\
\hline Bank Syariah Mandiri & $\sqrt{ }$ & $\sqrt{ }$ \\
Bank DKI Syariah & $\sqrt{ }$ & - \\
BTN Syariah & $\sqrt{ }$ & - \\
BNI Syariah & $\sqrt{ }$ & $\sqrt{ }$ \\
Bank Syariah Mega Indonesia & $\sqrt{ }$ & $\sqrt{ }$ \\
Bank Muamalat Indonesia & $\sqrt{ }$ & $\sqrt{ }$ \\
Bank Danamon Syariah & $\sqrt{ }$ & - \\
\hline
\end{tabular}

Disimpulkan bahwa terdapat 4 bank syariah yang sudah siap menerima deposito dalam bentuk mata uang asing, yaitu BSM, BNI Syariah, BSMI, dan BMI.

\section{Bagi Hasil dan Fasilitas Tambahan}

Penerimaan bagi hasil deposito diperoleh di awal atau akhir bulan, adalah tergantung atas kebijakkan bank, penerimaan bagi hasil tersebut disamakan untuk Rupiah atau mata uang asing dan berlaku untuk perusahaan maupun perorangan.

\begin{tabular}{lcc}
\hline \multicolumn{1}{c}{ Bank } & Diterima Di Muka & Diterima di Akhir \\
\hline Bank Syariah Mandiri & - & $\sqrt{ }$ \\
Bank DKI Syariah & - & $\sqrt{ }$ \\
BTN Syariah & $\sqrt{ }$ & $\sqrt{ }$ \\
BNI Syariah & $\sqrt{ }$ & $\sqrt{ }$ \\
Bank Syariah Mega Indonesia & - & $\sqrt{ }$ \\
Bank Muamalat Indonesia & - & - \\
Bank Danamon Syariah & $\sqrt{ }$ & \\
\hline
\end{tabular}

BNI Syariah dan BTN Syariah menerapkan aturan bahwa bagi hasil deposito dibagikan sama dengan tanggal pembukaan.

\section{Pembukaan Deposito}

Pembukaan deposito dapat dilakukan atas nama 1 orang atau 2 orang (joint account) dan sama halnya berlaku bagi deposito Rupiah maupun Dollar, tapi hal tersebut kembali kepada kebijakan bank

\begin{tabular}{lcc}
\hline \multicolumn{1}{c}{ Bank } & $\begin{array}{c}\text { Dapat Dibuka atas } \\
\text { Nama } \mathbf{1} \text { Orang }\end{array}$ & $\begin{array}{c}\text { Dapat Dibuka } \\
\text { atas Nama 2 } \\
\text { Orang }\end{array}$ \\
\hline Bank Syariah Mandiri & $\sqrt{ }$ & - \\
Bank DKI Syariah & $\sqrt{ }$ & - \\
BTN Syariah & $\sqrt{ }$ & $\sqrt{ }$ \\
BNI Syariah & $\sqrt{ }$ & - \\
Bank Syariah Mega Indonesia & $\sqrt{ }$ & $\sqrt{ }$ \\
Bank Muamalat Indonesia & $\sqrt{ }$ & $\sqrt{ }$ \\
Bank Danamon Syariah & $\sqrt{ }$ & \\
\hline
\end{tabular}

Disimpulkan bahwa terdapat 4 bank yang rekeningnya dapat dibuka atas nama 2 orang, yaitu BTN Syariah, BSMI, BMI, dan Bank Danamon Syariah 


\section{Pencairan Deposito}

Pencairan deposito pada umumnya dilakukan pada saat jatuh tempo, atau dapat juga dilakukan setiap saat tanpa menunggu saat jatuh tempo. Berikut kebijakan setiap bank responden:

\begin{tabular}{|c|c|}
\hline Bank & Persyaratan \\
\hline Bank Syariah Mandiri & $\begin{array}{l}\text { Dikenakan penalti Rp, 30.000,- dan bagi hasil bulan berjalan } \\
\text { tidak dibayar. }\end{array}$ \\
\hline Bank DKI Syariah & $\begin{array}{l}\text { Bagi hasil bulan berjalan tidak dibayar, dan tidak dikenakan } \\
\text { penalti }\end{array}$ \\
\hline BTN Syariah & $\begin{array}{l}\text { Bagi hasil bulan berjalan tidak dibayar, dan tidak dikenakan } \\
\text { penalti }\end{array}$ \\
\hline BNI Syariah & $\begin{array}{l}\text { Bagi hasil bulan berjalan tidak dibayar, dan tidak dikenakan } \\
\text { penalti }\end{array}$ \\
\hline $\begin{array}{l}\text { Bank Syariah Mega } \\
\text { Indonesia }\end{array}$ & $\begin{array}{l}\text { Tidak Dikenakan Penalti, Dan Bagi Hasil Bulan Berjalan Tidak } \\
\text { Dibayar. Tergantung Cabang Masing-Masing. }\end{array}$ \\
\hline Bank Muamalat Indonesia & $\begin{array}{l}\text { Dikenakan penalti Rp, } 50.000 \text {,- dan bagi hasil bulan berjalan } \\
\text { tidak dibayar. }\end{array}$ \\
\hline Bank Danamon Syariah & $\begin{array}{l}\text { Dikenakan biaya adminsitrasi Rp, 50.000,- dan bagi hasil bulan } \\
\text { berjalan tidak dibayar. }\end{array}$ \\
\hline
\end{tabular}

Disimpulkan bahwa pencairan deposito tanpa menunggu saat jatuh tempo, dan pihak manajemen bank tidak memberikan sanksi penalti atau biaya administrasi adalah Bank DKI Syariah, BTN Syariah, BNI Syariah, dan BSMI.

\section{Biaya Materai Deposito}

Biaya materai dikeluarkan setiap transaksi pembukaan atau penutupan deposito. Berikut data pembebanan biaya materai untuk setiap transaksi deposito:

\begin{tabular}{lcc}
\hline \multirow{2}{*}{ Bank } & \multicolumn{2}{c}{ Biaya Materai Deposito } \\
\cline { 2 - 3 } & Pembukaan & Penutupan \\
\hline Bank Syariah Mandiri & $\sqrt{ }$ & $\sqrt{ }$ \\
Bank DKI Syariah & $\sqrt{ }$ & $\sqrt{ }$ \\
BTN Syariah & $\sqrt{ }$ & $\sqrt{ }$ \\
BNI Syariah & $\sqrt{ }$ & - \\
Bank Syariah Mega Indonesia & $\sqrt{ }$ & - \\
Bank Muamalat Indonesia & $\sqrt{ }$ & - \\
Bank Danamon Syariah & $\sqrt{ }$ \\
\hline
\end{tabular}

Disimpulkan bahwa Bank Syariah yang tidak membebankan biaya materai untuk penutupan adalah BSMI, BMI, dan Bank Danamon Syariah.

\section{Lain-lain}

Keseluruhan responden bank syariah memberikan persyaratan yang sama dalam penempatan deposito perorangan maupun perusahaan. Untuk pembukaan dilakukan di kantor cabang bank-bank syariah dengan dilengkapi kartu identitas KTP/SIM/Paspor bagi warga negara indonesia dan Paspor atau KIMS/KITAS untuk warga asing. Sedangkan penempatan deposito untuk perusahaan harus 
dilengkapi dengan KTP/SIM/Paspor pejabat berwenang, SIUP, NPWP, pendirian perusahaan dan perubahannya yang terakhir, dan anggaran dasar perusahaan berikut perubahannya yang terakhir. Fasilitas lainnya dimana bagi hasil atas penyimpanan deposito yang diberikan dari bank syariah kepada nasabahnya secara keseluruhan dari ke 3 bank dan 4 UUS tersebut membolehkan untuk dapat diinvestasikan kembali ke pokok deposito, atau boleh juga ditransfer ke rekening tabungan, atau ditransfer ke rekening bank lain dengan dikenai biaya administrasi. Seluruh bank syariah responden membenarkan perolehan fasilitas kredit agunan bisa juga menggunakan deposito sebagai jaminan.

Fasilitas perpanjangan deposito diseluruh bank responden dilakukan secara otomatis. Sedangkan penyediaan fasilitas pembukaan dan penutupan rekening depositon harus dilakukan dengan manual yaitu datang ke bank dengan mendaftarkan diri dan mengisi formulir. Untuk pembukaan deposito Bank Danamon Syariah bisa dilakukan via telepon dengan syarat nasabah tersebut sudah memiliki buku tabungan. Sedangkan untuk pembatalan perpanjangan deposito secara keseluruhan responden bank syariah harus dilakukan secara manual atau datang langsung ke bank.

\section{SIMPULAN}

Penelitian perbandingan penawaran investasi deposito bank syariah dilaksanakan dengan mengadakan survey ke 3 bank syariah dan 4 UUS. Hasil perbandingan membuktikan untuk penilaian kelompok 1 yaitu Nisbah tertinggi diberikan oleh BNI Syariah dengan perbandingan $70 \%$ untuk nasabah deposito dan 30\% untuk bank. Kelompok 2 untuk persyaratan penempatan deposito Rupiah terendah bank syariah adalah Rp 1.000.000 (Bank Muamalat, BSMI, dan BNI Syariah), sedangkan yang tertinggi adalah Rp. 8.000.000 (Bank Danamon Syariah). Kelompok 3 untuk fasilitas, Bank Syariah Mandiri, BNI Syariah, Bank Syariah Mega Indonesia, dan Bank Muamalat Indonesia memiliki pilihan untuk mata uang asing, joint account dapat dilaksanakan di BTN Syariah, Bank Syariah Mega Indonesia, Bank Muamalat Indonesia, dan Bank Danamon Syariah. Untuk waktu pencairan deposito sebelum jatuh tempo, pihak manajemen bank yang memberikan keringanan dengan tidak memberikan sanksi penalti atau biaya administrasi adalah Bank DKI Syariah, BTN Syariah, BNI Syariah, dan BSMI. Sedangkan Bank Syariah yan tidak membebankan lagi biaya materai untuk penutupan adalah BSMI, BMI, dan Bank Danamon Syariah. Fasilitas lainnya seperti syarat administratif pembukaan deposito, waktu penerimaan bagi hasil penyimpanan deposito, dan perpanjangan deposito adalah sama dengan bank syariah pada umumnya

\section{DAFTAR PUSTAKA}

Afzal-ur-rahman. (1994). Dokrin ekonomi Islam, Dewan Bahasa dan Pustaka Kementerian Pendidikan Malaysia.

Anggraini L. (2010). BI: Deposito milik perorangan dominasi kenaikan DPK bank, Ekonomi dan Bisnis. Diakses tanggal 28 April 2010 dari http://www.waspada.co.id.

Infonews.com. (2009). Ada ruang pertumbuhan 40\%. Diakses tanggal 28 April 2010 dari http://cetak.infobanknews.com/artikel/rubrik/artike.

Muhammad. (2005). Manajemen Bank Syariah, edisi revisi, Yogyakarta: UPP AMPP YKPN. 